\title{
Multiple Team Membership (MTM) Implementation in the Construction Industry at D.K.I Jakarta, Indonesia; A Case Study Analysis
}

\author{
Jennyamor Ramadhani ${ }^{*}$, Ahyar Yuniawan ${ }^{2}$ \\ ${ }^{1}$ Faculty of Business and Economics, Universitas Diponegoro \\ Gang Rambutan No 143, Kudus, Indonesia \\ ${ }^{2}$ Faculty of Business and Economics, Universitas Diponegoro \\ Jl. Erlangga Tengah No.17, Semarang, Indonesia \\ *Corresponding author; Email: amorajenny97@gmail.com
}

\begin{abstract}
The number of activities in construction projects is increasing where the pace of development follows the development of rising funds with shorter time constraints. As a result, businesses have reacted by allocating people to numerous teams simultaneously. The purpose of this study is to explore the implementation of multiple team membership and the performance of workers as individuals and teams in the construction industry, especially in DKI Jakarta. In addition, this study also explores the appropriate approach to use so that projects carried out using MTM can run smoothly. This research employed qualitative research with a case study approach also used a structured interview method with purposive sampling of 20 workers. The location is in the construction industry in DKI Jakarta. It was found that the implementation of MTM on employees with higher positions provided more benefits than employees with lower positions. The benefits for higher employees are getting paid more, more insight, more relationships, and bids for future projects. Meanwhile, employees in lower positions only get broader insights. In addition, it was also found that the appropriate approach to use so that MTM projects can run smoothly is to improve multitasking abilities and manage schedules and strategies.
\end{abstract}

Keywords: Multiple Team Membership; Construction; Individual and Team Performance; MultiProject; Teamwork; Management.

\section{Introduction}

In general, the construction sector work progressed rapidly. The number of activities in construction projects is increasing where the pace of development follows the development of increasing funds with shorter time constraints (Siswanto \& Salim, 2019). Despite substantial transformation efforts to address global problems, this industry remains the least efficient compared to the manufacturing sector or the economy (Ozorhon \& Oral, 2017). To reap the benefits of innovation, practitioners must share information and expertise with other partners (Xue et al., 2018; Palumian et al., 2021). As a result, businesses have reacted by assigning people to numerous teams simultaneously, a process known as multiple team membership (MTM) (Gibson, 2018). Many people work on two or more projects at the same time under this situation, and it is feasible to share teams to profit from their knowledge at the same time (O'Leary et al., 2011).

According to research by Mortensen and Gardner (2017), multiple team membership (MTM) is increasingly common in various countries, industries and occupations.
Even though assigning employees to multiple projects at once is not new, the practice is prevalent today. In a survey of more than 500 managers in global companies, we found that $81 \%$ of those working on teams worked on more than one concurrently (Mortensen \& Gardner, 2017. Other research done by Martin and Bal (2015) places the number even higher, for example, $95 \%$ in knowledge-intensive industries. Unfortunately, research about MTM has only been carried out in developed countries, for example, in the Netherlands, namely in the fields of software development, civil engineering, public policy analysis (van de Brake et al., 2019); in Romania, South Africa, the United States, and China in information technology and engineering (Chan, 2014; G. Chen et al., 2019; Pluut \& Flestea, 2014) in Sweden in manufacturing, pharmaceuticals, and construction (Zika-Viktorsson et al., 2006). The common problem of the teams is that "multiple team memberships," or MTMs for short, can increase employees' stress (Pluut \& Flestea, 2014) and role overload (Zika-Viktorsson et al., 2006), which makes it very difficult for employees to fulfill all of their roles effectively. During the workweek, and even within a single weekday, MTM employees regularly move between their 
various tasks, which might reduce their capacity to focus well on each project (Smith et al., 2018).

Being allocated to several tasks is more stressful and less effective for many people than theory implies. Switching attention between tasks is time-consuming and exhausting. Changing teams also necessitates adapting to new duties. Different teams have distinct cultures, including connections, routines, symbols, humor, expectations, and tolerance for ambiguity, all needing the energy to manage (Gardner \& Mortensen, 2017).

Years of research and study that discuss the secret of excellent teamwork by Haas and Mortensen (2016) have taught us that these ingredients are unclear missions, inconsistent social norms, low common identity, unclear roles, and unstable membership are the recipe for team disasters. They result in inefficient, often unproductive, teams full of disconnected, sometimes disgruntled, members (Mortensen \& Hadley, 2020).

A previous study in the Netherlands performed by van de Brake (2019) looked at the benefits and drawbacks of applying MTM to individual personnel in applied research firms. The findings of their study demonstrate that the adoption of MTM can help individual workers meet their inherent desire for difficult work situations while also improving their job performance. However, it turns out that this effect happens only among workers in relatively high positions, but individuals in relatively low positions would feel disadvantaged due to role ambiguity, which will lower employee performance and increase their absence from work.

Previous studies on O'leary (2011) primarily looked at individual employee performance rather than team performance. However, the study claims to give empirical evidence for an inverse U-shaped link between MTM and individual performance at the personal level. In other words, when an individual is active in several teams simultaneously, his inventive performance will initially be strong. Still, as the number of MTMs taken rises, his innovative performance will begin to drop. So, in general, the number of project team members impacts individual performance.

DKI Jakarta is the nation's capital and largest city in Indonesia. Jakarta has about $664.01 \mathrm{~km} 2$ area and a population of $11,100,929$. Moreover, the construction sector is one of the most significant contributors to the economy in DKI Jakarta Province. In 2019, this sector contributed around $11.61 \%$ of Jakarta's total GRDP. Likewise, the construction sector plays an essential and strategic role in national develop- ment at the national level as a barometer of national economic growth and employment. This evidence is one of the reasons why a study on MTM should be conducted in Indonesia, precisely in the industrial sector spread across DKI Jakarta (BPS, 2020).

Despite this great insight, several important research questions remain unanswered in this context, especially those related to the application of MTM in other fields such as the construction industry. The reason is that the construction industry often uses project work systems (Chan, 2014), implementation of MTM, and employee performance in Asian countries such as Indonesia, as well as what is the appropriate approach in implementing MTM projects to run smoothly (van de Brake et al., 2019). We aim to research these three topics. Therefore, we pursue the following research questions:

RQ1: What are the current perceptions of the construction industry workers in DKI Jakarta with regards to MTM implementation?

RQ2: To what extent do the construction industry workers in DKI Jakarta perform under the MTM implementation?

RQ3: What are the appropriate approaches to ensure that MTM runs smoothly on projects in the construction industry in DKI Jakarta Province, Indonesia?

\section{Literature Review}

\subsection{Multiple Team Membership}

Multiple team membership (MTM) is a type of work organization in which individuals join two or more groups at the same time for a set period (O'Leary et al., 2011) or as a form of membership interdependence between teams (Margolis, 2020). Being a member of one or several teams creates a social learning context through open interpersonal interactions. Individual members are exposed to various team settings in MTM, which are predicted to provide more significant learning and growth possibilities than single team membership (Chen et al., 2020; O'Leary et al., 2011) timely input before the project is begun.

Academics have defined individual MTM as a complicated concept with several aspects, including the number of concurrent teams a person has and the variety (e.g., in terms of task, function, or technology) (O'Leary et al., 2011). As a result, individual MTM is defined as the 
number of teams to which workers assign work time within a certain period (e.g., per week) (van de Brake et al., 2018). When the MTM is greater, an employee is involved in a more significant number of teams simultaneously, but when the MTM is smaller, an employee is only active in one or a few teams at a time.

Although the majority of MTM research focuses on the perspective of the project manager, academics have lately begun to study the impact of working in many teams at the same time on the complexity of team members' jobs. However, most studies focus on individual outcomes such as productivity and learning (Alfaro, 2015).

\subsection{Construction Project Management}

A project is a collection of activities and tasks with particular goals that must be completed within specific parameters, such as established start and finish dates and budget restrictions. (Kerzner, 2017).

Construction is an activity that produces a structure or construction connected with the local land of its location, whether it is utilized as a residence or a means of carrying out other activities. Buildings, roads, bridges, rail and railway bridges, tunnels, water and drainage structures, sanitation buildings, aviation runways, ports, power generating buildings, transmission, distribution, and communication network buildings are among the outcomes of these operations (BPS, 2020).

Careful resource planning in line with the project's logical demands will aid in achieving the project's goals and objectives to the greatest extent possible while maintaining a high degree of effectiveness and efficiency. The resource requirements for each project are not always the same, but it depends on each project's scale, location, and level of uniqueness. However, resource planning can be calculated using a mathematical approach that gives optimal results compared to just an estimate of experience, which has a low level of effectiveness and efficiency (Siswanto \& Salim, 2019).

Human resources in a project can be categorized as permanent workers and temporary workers. The division of this category is intended so that the company's efficiency in managing resources can be maximized with an adequate economic burden. The company usually manages workers with permanent status with monthly fixed salary payments and other facilities to maintain employee productivity. On the other hand, the existence of temporary workers is intended to avoid additional burdens by paying monthly salaries and adjusting the number of labor as required accordingly (Siswanto \& Salim, 2019; Setyawan et al., 2020).

\subsection{Team and Individual Performance}

Performance is an essential concept for understanding individual contributions to the organization and is defined as individual behavior that produces value (Campbell \& Wiernik, 2015). One of the factors supporting the success of a project is the performance of the project team, which consists of all workers who actively participate in handling construction project organizers. The project team must be well managed. Therefore, a leadership role in the project work team is needed to improve project performance from the beginning to the end (Pratiwi, 2019).

Performance is an engine driving the company (Palumian et al., 2021). Individuals in the company are the company's most important resource (Setyawan et al., 2020). Consequently, excellent individual performance and having skills following the company's needs will benefit the company. Individual performance is the foundation of a company. Therefore, it is crucial to understand the behavior of several individuals in the company to be used as a reference to assess the performance of an individual who works in a company (Antika et al., 2020).

Another definition is that individual performance can record one's achievements. Finally, team performance is defined as performance assessed by relevant others outside the team or its report (Baron \& Armstrong, 2007).

\subsection{How to stay focused on working MTM}

Being dragged across several tasks is unpleasant and less effective for many people than theory implies. Switching tasks takes time and saps your concentration and stamina. You may need to adjust to new duties when you move across teams. For example, you may be the captain on one squad, while you may be a junior on another. Different teams have their own cultures, including connections, routines, symbols, humor, expectations, and ambiguity tolerance, all of which require energy to manage. Research by Gardner and Mortensen (2017) found that there are several ways to focus if you are assigned to multiple projects at the same time: 


\section{A. Prioritizing and doing work sequentially}

If we want to focus on doing many tasks simultaneously, we must be able to prioritize which work to do first based on its interests and deadlines. Besides that, we also have to develop strategies or ways to do our work because our work will be more organized and efficient, also easier to work with. It would be better if we move between jobs or tasks in a short time because Leroy (2009)research states that if we make the transition between jobs in a short time, it will have an impact on our level of focus or concentration, which causes our work to be hampered.

\section{B. Managing communication}

In working with MTM, we must also manage our communication, as Gardner and Mortensen (2017) mentioned. If we are doing work with high priority and requires high concentration, we are allowed to inform our co-workers if we are not available to communicate with, for example, by turning off the device, informing colleagues if we are not in a fast response state, and making automatic messages in emails that we can contact colleagues later when our work is finished.

\section{Optimizing self-development}

Working in MTM is not always detrimental. Sometimes, we can take the positive side. For example, we can develop ourselves and know our limits in doing a job. If working with MTM for beginners, of course, we can't immediately do our work perfectly. However, with more diverse experiences through MTM, we can develop ourselves to be better and competent in our fields. Furthermore, if we make mistakes in working with MTM, we can reflect on ourselves and find out our shortcomings in doing our previous work so that if we are assigned to MTM in the future, we can work better.

The collection of literature above can help the author in this study. For example, the author will study whether the construction industry that also applies MTM has the same way as described by Gardner \& Mortensen (2017), or construction workers have different ways of handling their work while implementing MTM in their work. If other methods are found, this literature can add to broader knowledge and information about the appropriate ways to make MTM workers focus on working in different industries.

\section{Methods}

\subsection{Data and Study Design}

A qualitative investigation with a case study method is used in this study. Purposive sampling was employed to collect data. Qualitative research describes an event in its natural setting (Abusabha $\&$ Woelfel, 2003). It is a subjective way to look at life and explain the studied behavior (Walsh, 2003). Because case studies can enable the examination of a phenomenon in its context by combining multiple data sources, they are employed. This guarantees that problems are not examined through a single lens but rather via various lenses that expose various elements of the phenomena (Baxter \& Jack, 2015). Purposive sampling was chosen because it is one of the most frequent qualitative research techniques, dividing participants into groups based on pre-determined criteria relevant to the study issue (Mack, 2005). The following is depicted in Figure 1 to help clarify things.

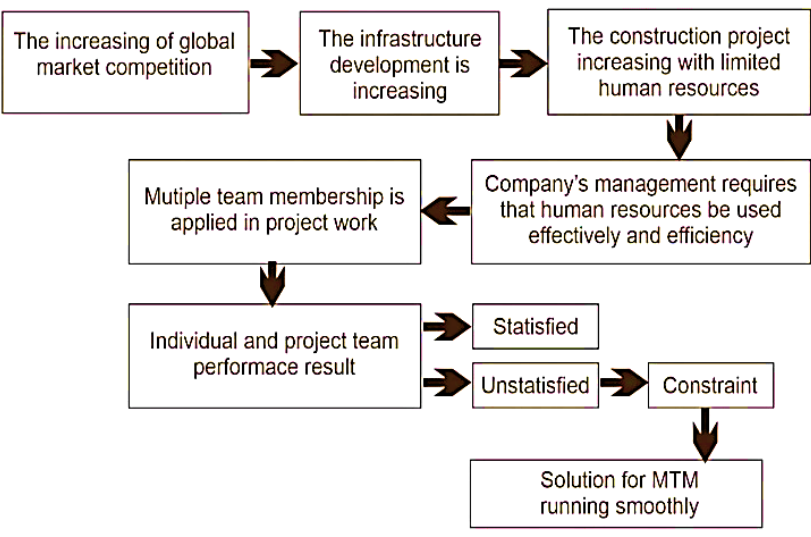

Figure 1. Research Framework

Source: Developed for this study (2021)

In Figure 1, the researcher makes the research framework easier for readers to explore this research. This research can occur starting from the increasing competition between markets in this decade, especially of infrastructure development in Indonesia, making the construction market also passionate about carrying out development. However, the companies that oversee the construction are aware that with limited human resources, they place their human resources in several projects simultaneously so that the project can run effectively and efficiently. However, the practice of MTM has resulted in various responses from workers. For this reason, this research was conducted so that readers can 
find out more precise information on the application of MTM in the construction industry in Jakarta, Indonesia.

\subsection{Sample}

There is a recruiting strategy, a projectspecific plan to find and enroll people to participate in a research study before the sample is chosen. The plan should specify the criteria for evaluating possible participants, the number of individuals to be recruited, the location, and the method to be utilized. Some of the questions that may occur during participant recruiting are addressed in this section.

The sample of this research will then be referred to as informants. Informants who participated in this study amounted to 20 contract workers or permanent workers in the construction industry in DKI Jakarta, Indonesia. The informants consisted of 8 female workers and 12 male workers. The demographic data of the informants in this study can be seen in Table 1. In addition, the worker must have met the following criteria to be a resource person in this study:

A. Employees who work in the project-based medium to the large-scale construction industry sector in DKI Jakarta, Indonesia.

B. Indonesian citizen and have worked in the construction industry sector in Indonesia for at least two years.

C. Have held more than one project at the same time from the same company or different companies.

D. Have worked with other employees from the same or different fields.

E. Have followed more than one different team at the same time.

\subsection{Measure}

The interview approach will be used to collect data for this investigation. A structured interview is the sort of interview that will be used. Structured interviews entail asking all participants the same set of interview questions in a research project. This framework ensures that everyone has an equal chance to contribute data to the same research constructs (Given, 2012).

The interviews conducted lasted 20-30 minutes. The interview questions totaled 39 items. These interview questions were taken and selected based on previous research (Alfaro, 2015; de Visser et al., 2014; Mortensen et al., 2007; Soyemi, 2018) with additions and modifications.
The types of data generated by this method are field notes, audio recordings (sometimes video), and transcripts (Mack, 2005). Interviews were conducted online due to a pandemic, which resulted in restrictions on activities outside the home. An indirect interview means an interview that can be done by telephone or video call. This method is carried out for selected informants who are willing to be interviewed but cannot meet in person due to many things such as busy working hours, restrictions on activities outside the home due to a pandemic, or other personal matters. The drawback is that researchers are limited by communication, which sometimes includes noise, signals, and a less conducive atmosphere (Mack, 2005).

Table 1. Profile of Informants

\begin{tabular}{|c|c|c|c|c|c|}
\hline $\begin{array}{l}\text { Infor- } \\
\text { mant }\end{array}$ & Age & Gender & Education & $\begin{array}{l}\text { Experiences } \\
\text { (Years) }\end{array}$ & $\begin{array}{c}\text { Work } \\
\text { Position }\end{array}$ \\
\hline 1 & 25 & Female & $\begin{array}{l}\text { Environmental } \\
\text { Engineering }\end{array}$ & 2.0 & HSE Staff \\
\hline 2 & 25 & Female & $\begin{array}{l}\text { Environmental } \\
\text { Engineering }\end{array}$ & 2.0 & HSE Staff \\
\hline 3 & 25 & Female & $\begin{array}{l}\text { Environmental } \\
\text { Engineering }\end{array}$ & 1.5 & HSE Staff \\
\hline 4 & 30 & Male & Geology & 5.0 & $\begin{array}{l}\text { Project } \\
\text { Manager }\end{array}$ \\
\hline 5 & 30 & Male & Geology & 7.0 & $\begin{array}{l}\text { Project } \\
\text { Manager }\end{array}$ \\
\hline 6 & 30 & Male & Geology & 6.0 & $\begin{array}{l}\text { Project } \\
\text { Manager }\end{array}$ \\
\hline 7 & 25 & Female & Law & 2.0 & Legal Staff \\
\hline 8 & 26 & Female & Law & 2.0 & Legal Staff \\
\hline 9 & 30 & Male & Geology & 5.0 & $\begin{array}{l}\text { Project } \\
\text { Manager }\end{array}$ \\
\hline 10 & 29 & Male & $\begin{array}{l}\text { Civil } \\
\text { Engineering }\end{array}$ & 4.0 & $\begin{array}{l}\text { Structure } \\
\text { Engineer }\end{array}$ \\
\hline 11 & 29 & Male & $\begin{array}{l}\text { Civil } \\
\text { Engineering }\end{array}$ & 4.5 & $\begin{array}{l}\text { Draft } \\
\text { Engineer }\end{array}$ \\
\hline 12 & 29 & Male & $\begin{array}{l}\text { Civil } \\
\text { Engineering }\end{array}$ & 3.5 & $\begin{array}{l}\text { Draft } \\
\text { Engineer }\end{array}$ \\
\hline 13 & 26 & Female & Management & 2.0 & Procurement \\
\hline 14 & 29 & Male & $\begin{array}{l}\text { Civil } \\
\text { Engineering }\end{array}$ & 4.0 & $\begin{array}{l}\text { Structure } \\
\text { Engineer }\end{array}$ \\
\hline 15 & 26 & Male & Architect & 2.0 & HSE Staff \\
\hline 16 & 26 & Female & Law & 2.0 & Legal Staff \\
\hline 17 & 27 & Female & Law & 2.5 & Legal Staff \\
\hline 18 & 27 & Male & Law & 4.0 & Legal Spv \\
\hline 19 & 28 & Male & Architect & 2.5 & $\begin{array}{l}\text { HSE } \\
\text { Supervisor }\end{array}$ \\
\hline 20 & 28 & Male & Architect & 3.0 & $\begin{array}{l}\text { HSE } \\
\text { Supervisor }\end{array}$ \\
\hline
\end{tabular}

Resources: Interview with the informant

\subsection{Data Analysis}

The data analysis in this study adheres to the theory formulated by Yin (2015). There are five methods in the analysis of qualitative research: compiling data, deconstructing data, merging data, analyzing data, and concluding data. Concerning this theory, the researchers applied the method into this study with a slightly different research style and modified it according to the 
circumstances and conditions when this research was conducted.

The first stage of data analysis starts from data that has been collected from interviews with informants in the form of voice and video recordings collected first. The second stage is to change the data that was previously in the form of voice or video recordings into writing to become a neater and easier-to-understand script. This manuscript will be the primary data in analyzing the answers from the informants. When conducting interviews with informants, the researchers used Indonesian. Therefore, the researcher translates from Indonesian to English at this stage, which is contained in this study. The selected informants are the most suitable candidates for this study because their qualifications follow those in the sample criteria that the researcher has determined. In addition, most of the informants have co-worker relationships with researchers who also work in the construction industry. The third stage is selecting data and combining the data that most often appears from the informants' answers. It can be seen which data is representative of the results of each question asked by the interviewer to the informant. The fourth stage is compiling or interpreting the answers that most often appear in the table. Then they will be compiled into a narrative to make it easier for researchers to convey the results of this research to the readers. The fifth stage is to conclude the data that has been compiled according to their respective themes. From this conclusion, it is found that research results can answer the research questions that have been mentioned previously in the introduction section above.

\section{Results}

\subsection{Implementation of Multiple Team Membership in the Construction Industry}

All interviewees said that the practice of MTM is very common in the construction industry, but indeed they admit that each of them is very foreign to the term MTM. All the informants stated that they have been doing MTM projects either with company employees or employees from outside the company.

Most of the projects they work on are all from the same company. Often companies get projects simultaneously, so companies put their employees on many projects at once to take advantage of the efficiency and effectiveness of the project. As for companies that lack human resources, look for workers from outside parties with contractual agreements or only through relations with their employees. For example, employees with high positions, such as project managers, say that they have received project offers from outside the company, such as their relationships that require the employee's abilities. However, employees with lower positions, such as staff, only work on projects assigned by the company.

On average, the projects they work on are outside DKI Jakarta. However, they still regularly visit the head office located in DKI Jakarta to report the results of their work to company leaders in the form of reports and presentations. They are working on examples of projects: the SerangPanimbang TOL project, the Bengkulu-Sumatra TOL project, the East Kalimantan Lawe-lawe terminal construction project, the Ambon Port project, and many other projects that they cannot mention because they carry company secrets.

Informants stated that the projects they worked on significantly varied, but the average minimum duration was six months and a maximum of 1 year. If the project is offered and carried outcomes from within the company, the person who assigns it is its head. Still, if you get a project offer from outside, there is usually a request from relations outside the company.

Informants who work in this sector said their working hours are often more than the provision (8-9 hours). The reason is that the working hours in this sector are flexible and do not require employees to work full time, but sometimes they only worked half a day yesterday, but today they have to work more than 9 hours. This is one of the causes of informants who do not like working MTM because the number of projects that must be done with other teams is increasing, resulting in them continuously working overtime.

According to the informant, it is inevitable that when they work on MTM projects, they feel losses, including fatigue, because they must divide time between different jobs, meet with different teams on each project, commute between projects that have far apart locations. This situation can lead to a stress condition. This situation is felt for every employee with various job descriptions and from any position (staff to manager).

Although they feel there are disadvantages, they can also feel the advantages behind implementing MTM. However, research proves differrences in employees with low positions (staff) and higher positions (managers, supervisors). 
Employees who have staff-level posts only get benefits in the form of experience, knowledge, and new abilities but do not get additional pay. They also get new relationships but only relationships. In contrast to employees who have a manager or supervisor level position, they get benefits in the form of project bonuses if the project is successfully carried out, gain new knowledge and skills because each project usually has different types of projects. The most important thing is to get relationships that are not just getting acquaintances. Even though it is still new, it can lead to future benefits because of new relationships. They can exchange information and offer each other projects because usually projects are carried out from within the company and from employees outside the company.

Due to the advantages that higher-ranking employees get, they stated that they like working with the MTM system and are willing to be given another opportunity. However, lower position employees think that if they can choose, they do not want to work MTM because the perceived loss is more significant, and they do not like it.

I 7: "I honestly don't like the MTM system as a staff because they have no choice but to accept any project and how much the boss gives them. This makes the staff very tired due to the increased workload and requires us to work overtime continuously. In addition, our company does not provide overtime compensation which makes us prefer to work on one project at a time or only a small number of projects."

This study shows that the application of MTM to employees who have high and low positions is not the same. The advantages and disadvantages of implementing MTM in the construction industry vary according to employees' high and low positions. Although they still feel there are advantages and disadvantages in undergoing MTM, they still feel different things. More details on how the application of MTM in the construction industry in DKI Jakarta Indonesia can be seen in Figure 2.

\subsection{Individual and Team Workers Performance}

As explained in the background of this study, previous research primarily examined individual performance on MTM only. In contrast, this study examined the individual performance and overall team performance. For individual performance appraisals, each informant assessed their performance while implementing MTM in their project. The study results prove that the informants are satisfied with their respective performance even though they have to apply MTM in working on their projects. This is because even though they have to join many teams simultaneously, their performance remains stable and even increases. Besides that, their work can run smoothly according to the pre-determined targets. This is evidenced by the answers of the informants as follows:

I1: "I am satisfied with my performance because there were no work accidents or major problems while I was working on my project."

I3: "So far, because the projects I work on are always following the initial objectives, completed according to the target, and the obstacles that occur can still be overcome within reasonable limits and do not harm the company or employees."

I13: "Yes, I am satisfied with my performance because I can join many teams and projects."

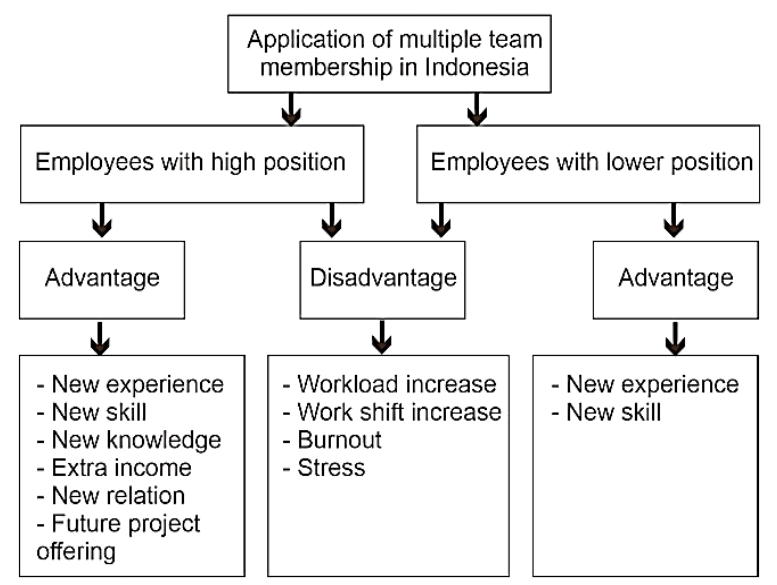

Figure 2. The findings from Implementation of MTM in the Construction Industry in DKI Jakarta, Indonesia Source: Analysis of Interview Result

Some leaders who were asked to assess individual performance and overall team performance felt that employees in high positions such as supervisors or engineers could be said to be more satisfactory than staff employees. This finding can happen because of the possibility that the leadership to pressures staff employees to complete the MTM project correctly with inappropriate reciprocity. 
I5: "I feel that the performance of my team members in higher positions (engineering and supervisors) have more satisfying individual performance than staff employees. This condition may occur because the benefits obtained from MTM are more for supervisors and engineers than staff employees. So, I think that MTM can affect individual performance based on the benefits derived from MTM".

\subsection{Appropriate Approachers to Ensure that MTM Runs Smoothly}

In applying MTM in the construction industry, it is proven that MTM is common to be applied in the work system of construction projects in Jakarta. However, not all MTM applications are easy to implement for employees in the construction industry. This research can help workers in the construction industry apply MTM to make their work smoother. Based on the analysis of the answers given by informants who use MTM in their work, ranging from those who are inexperienced to those with years of experience, it is stated that several approaches or methods can be implemented for fellow MTM workers in the construction industry. The first way is to implement and improve the ability to multitask. Multitasking means workers can do multiple jobs in close time intervals. For example, as suggested by Informant 6, a construction worker who has a job description as a legal staff said:

I6: Improving multitasking is very important when working in MTM while working in MTM requires me to apply my multitasking skills at work. For example, when I get an order to take care of the legal documents for various projects, they usually come together. So inevitably, I have to work on it simultaneously so that when asked by the leadership how far the progress is, I can answer that the two projects I am working on are almost complete.

The second way besides multitasking is to maintain communication between team members. In working as a team or individually, there must be communication between team members and other workers. For MTM to run smoothly, open and honest communication is needed to understand each other and understand what each worker needs. If there is even the slightest misscommu- nication, it will be fatal and can harm the workers who do their work and people related to the work to harm the ongoing project. Therefore, smooth communication between superiors to subordinates or between fellow workers is needed to avoid project losses. As has been experienced by one of the informants two as a representative who chooses communication is one way to make MTM run smoothly saying as follows:

I2: I think maintaining communication is the most important thing. I once had a miss communication experience with my boss where I should have replaced my boss to present the results of a month's project work to the company leader. However, I did not carry out the order due to improper communication, which became over-whelming for my team. Since then, I have consistently improved my communication style with whoever it is so that no more misunderstandings can harm the project team I work with.

The last way that can help the MTM work smoothly is to set the time and strategy in doing the task or work. If we have a lot of work and must be completed simultaneously and we manage the time and strategy to do these jobs will help us in completing all the work. This was stated by informant five, who worked as a project manager having seven years of experience as a representtative of all informants, who suggested the following:

I5: From me, I must manage time well and arrange work schedules so that they don't collide with each other. If we can manage the time and work schedule well, we can know which work is a priority and must be done immediately because the deadline is approaching. That way, even though we work on an MTM basis, our work can be more organized and completed before the deadline arrives so that even our superiors will be happy with our performance while implementing MTM.

\section{Discussion}

The material revealed during informant interviews has been analyzed to create a fresh and more extensive picture of how multiple team membership is used in the construction sector. Senior managers and team leaders worldwide are becoming increasingly upset by the problems that 
come from MTM or having employees allocated to several projects simultaneously. However, because of the numerous advantages of MTM, it has become a way of life for businesses, particularly in knowledge work. Hence, individual time and brainpower can be shared across functional lines and departments.

MTM has been demonstrated in previous studies to help employees learn more diversified professional knowledge, create possibilities for career advancement, increase knowledge transfer between teams, and improve job efficiency and employee knowledge acquisition capacities (Chen et al., 2020). It is proven in this study that MTM does provide many benefits for employees who work MTM. However, this only applies to employees with high positions such as project managers, supervisors, and team managers. They believe that the benefits outweigh the disadvantages, such as getting additional income (if receiving many projects, employees usually get a bonus according to the number of projects), gaining diverse and broader knowledge, abilities, and experiences (usually projects offered of various types). The most crucial thing is getting relationships from within and outside the company because employees with higher positions get more trust. If they are lucky, projects from outside the company can also be offered, as indicated by the answer of one of the informants of this research. On the other hand, employees with lower positions feel more fatigue and workload without additional income.

Previous researches indicated that MTM have positive and negative effects on individual performance and well-being (Chen et al., 2020; O'Leary et al., 2011; Pluut \& Flestea, 2014; Rapp \& Mathieu, 2019). Moreover, more and more empirical studies have examined the benefits and disadvantages of MTM (Margolis, 2020). The results of previous studies showed that they found evidence that implementing MTM is potentially beneficial for individual employees because it can fulfill the intrinsic need for challenging work experiences and strengthen their job performance. However, it turns out that this result only occurs among employees with relatively high positions. In contrast, employees with relatively low positions will feel disadvantaged because they feel role ambiguity, decreased employee performance, and increased their absence from work (van de Brake et al., 2019). This result is also evident in this study, which shows that individuals and teams with high positions have satisfactory performance. In contrast, those in lower positions have low performance. However, suppose performance is assessed individually or as a team. The performance of employee will be considered satisfactory as long as they do not have any problem in performing the project.

This research wants to prove that research of Gardner \& Mortensen's (2017) is applicable on employees who work in MTM for the construction industry in Jakarta, Indonesia. This study proves several approaches so that workers in the construction industry can smoothly use MTM. The first approach is that workers can improve their multitasking abilities. Multitasking can be applied when workers have a lot of work with different teams and must be done simultaneously. Therefore, workers who multi-task must transition between their jobs in short time intervals. This is not in line with the research of Gardner \& Mortensen (2017), which suggests that you should focus on one job first until it is finished only if after completion the worker can move to another job. All workers can indeed do this method. Still, based on the answers from our informants, they are more comfortable if they can do many things at once because, based on their experience, superiors often demand progress of work that is running rather than quick results.

The second approach in this study is to maintain communication between team members and other co-workers. This is done so that there is no misunderstanding in communication that causes errors in doing work. The research of Gardner \& Mortensen (2017) also proposes maintaining communication. Still, the context is different because they propose to stay away from communication tools and tell their co-workers not to be disturbed. At the same time, workers have to focus on doing MTM tasks. At the same time, our informants suggested that keeping communication is more about the workers' communication style to be more open and honest. For example, suppose there is a problem at work. In that case, it can be shared with other team members to help or just provide assistance because the project work system always prioritizes teamwork even though each team member has their duties.

The third approach is to manage the time and strategy at work. For this reason, the informants agreed and suggested applying this method to MTM workers. Moreover, the informants also suggested that managing time and strategies at work enables the worker to finish their jobs quickly, and smoothly according to the plans that have been made. Therefore, the workers know 
which jobs must be prioritized and must be done first. The workers who apply this method can perform better and can satisfy both the team and their supervisor.

The researcher hopes to provide a broader picture and information. The construction industry that adheres to a project work system, it is proposed to use MTM as part of the daily life of its workers. The application of MTM can provide benefits for both employees and companies. Still, behind that, there must be losses in the application of MTM. At this moment, the author provides an overview of how the application of MTM can run smoothly so that the losses obtained can be minimized.

The results of this study offer several practical implications. They show that MTM in the construction sector is as necessary as other industrial sectors that play a project work system or team collaboration. This study suggests that the advantages and disadvantages obtained or felt by each employee in the construction sector vary depending on the level of their position. Employees with higher positions feel more benefits than losses, and they are very willing to be allowed to work MTM again in the future. In comparison, employees with lower positions feel more losses than benefits and prefer not to work MTM if they choose. Therefore, employees with high and low positions are expected to apply the appropriate approach so that projects carried out by MTM can run smoothly not cause fatigue and stress. Approaches that can be taken include improving multitasking abilities, managing schedules and strategies in working on projects, and maintaining good communication between team members. It is also hoped that employees who have higher positions will help employees who have positions below them not to give too heavy a burden and propose to company leaders to give them the feedback they deserve due to their hard work.

This study has some relevant contributions to the MTM literature and opens a new place to explore learning outcomes derived from MTM, but it also has some limitations. This study was conducted during the corona pandemic throughout the world. This resulted in interviews that should have been conducted face-to-face with selected informants to be conducted online. The intermediaries used include video calls, conference calls, and telephones. This creates disturbances such as signal problems because several informants are carrying out project assignments in remote areas. Communication is limited because face-to-face interviews are usually more flexible and can be observed from the side of the movements or the psychological side of the informant. To reduce the limitations of this study, we continue to try to find the right time to conduct interviews so that disturbances that can occur can be minimized. Therefore, this research takes a long time because it is difficult to find a suitable time between researchers and informants.

For future research agendas, it is possible to examine the topic of MTM from different perspectives, such as from different industrial fields and different coverage areas. This is done so that the results of these studies can complement each other and add insight to the previously existing MTM topics. Researchers suggest that further research can be carried out directly during the corona pandemic because it can hinder the research process.

Another possible source of worry is that our data lack objective information regarding employee job performance (outside of individual supervisor ratings). It's feasible, for example, that team supervisors are more favorable in their assessments of employees who work in numerous teams, regardless of the individuals' actual performance outcomes (Watson \& Pennebaker, 1989). Therefore, future research might benefit from a more detailed examination of the indirect relationship of MTM to the objective and subjective performance of employees. It would be better if future research also examines this topic using quantitative research to compare the results and get more definite and accurate results.

\section{Conclusions}

This study reveals the application of MTM in the construction sector in DKI Jakarta Province, Indonesia, where it is found that the application of MTM makes employees in high positions feel more benefits than losses. In contrast, employees with lower positions feel more losses than gains. Employees who have high positions feel that when they apply MTM in projects, they get more benefits such as increased income, increased knowledge, insight, skills, and increased relationships. Employees with low positions get more losses, such as feeling fatigued and workload more without any additional income. They only do the work that their superiors have arranged without having the right to choose. Therefore, most of them are not willing if they may choose not to work on many projects simultaneously.

This study also found that overall individual and team performance satisfies the leaders after 
implementing MTM. This is because when implementing MTM, individuals who are members of different teams can work together and help each other work on their projects. In addition, this study also suggests using an appropriate approach in working on MTM projects to run smoothly by improving multitasking abilities, making appropriate strategies and schedules, and maintaining good communication between team members. The researcher hopes that these findings will stimulate further research on MTM from different perspectives (e.g., different industries and countries) so that MTM is better known in all industrial circles.

\section{References}

Abusabha, R., \& Woelfel, M. Lou. (2003). Qualitative vs Quantitative Methods: Two Opposites That Make A Perfect Match. Journal of the American Dietetic Association, 103(5), 566-569.

Alfaro, I. (2015). The Impact of Multiple Team Membership on Individual Creativity. University of Illinois at Chicago. figshare.com/articles/thesis/The_Impact_of_ Multiple_Team_Membership_on_Individual_ Creativity/10832135/1

Antika, P. P., Junaidi, \& Hariri. (2020). Pengaruh Kinerja Individu, Kecanggihan Teknologi, dan Kemampuan Pengguna Terhadap Kualitas Sistem Informasi Akuntansi (Studi Kasus pada Kantor Pusat PT. Pos Indonesia Kabupaten Pati). E-Jra, 9(2), 47-57. riset.unisma.ac.id/ index.php/jra/article/view/8423

Baron, A., \& Armstrong, M. (2007). Human Capital Management: Achieving Added Value Through People. Kogan Page Publishers. doi.org/10.1108/hrmid.2008.04416eae.001

Baxter, P., \& Jack, S. (2015). Qualitative Case Study Methodology: Study Design and Implementation for Novice Researchers. The Qualitative Report, January. doi.org/ 10.46743/2160-3715/2008.1573

BPS. (2020). Direktori Perusahaan Konstruksi Provinsi DKI Jakarta 2020. jakarta.bps.go.id/ publication/2020/12/23/a84cd40919d4fae957 d6b384/direktori-perusahaan-konstruksiprovinsi-dki-jakarta-2020.html

Campbell, J. P., \& Wiernik, B. M. (2015). The Modeling and Assessment of Work Performance.

Chan, K. (2014). Multiple Project Team Membership and Performance: Empirical Evidence From Engineering Project Teams Theoretical framework and hypotheses. South African Journal of Economic and Management Sciences, 17(1), 76-90. doi.org/10.4102/ sajems.v17i1.875

Chen, G., Smith, T. A., Kirkman, B. L., Zhang, P., James Lemoine, G., \& Farh, J. L. (2019). Multiple Team Membership and Empowerment Spillover Effects: Can Empowerment Processes Cross Team Boundaries? Journal of Applied Psychology, 104(3), 321-340. doi.org/10.1037/ap10000336

Chen, H., Jiao, J., Yang, N., \& Wang, X. H. (2020). How Identity Conflict and Identity Synergy Influence Innovative Performance of Employees With Multiple Team Membership. Psychological Reports, 19. doi.org/10.1177/ 0033294120916863

de Visser, M., Faems, D., Visscher, K., \& de Weerd-Nederhof, P. (2014). The Impact of Team Cognitive Styles on Performance of Radical and Incremental NPD Projects. Journal of Product Innovation Management, 31(6), 1167-1180. doi.org/10.1111/jpim. 12247

Gibson, H. (2018). Multiple Team Membership, Turnover, and On-Time Delivery: Evidence From Construction Services. 39th International Annual Conference of the American Society for Engineering Management, ASEM 2018: Bridging the Gap Between Engineering and Business, 352-361. www.hbs.edu/faculty/ Pages/item.aspx?num=60746

Given, L. (2012). The SAGE Encyclopedia of Qualitative Research Methods. In The SAGE Encyclopedia of Qualitative Research Methods. doi.org/10.4135/9781412963909

Kerzner, H. (2017). Project Management: A Systems Approach to Planning, Scheduling, and Controlling. John Wiley \& Sons. https://www.wiley.com/en-

us/Project+Management $\% 3 \mathrm{~A}+\mathrm{A}+$ Systems+A pproach+to+Planning $\% 2 \mathrm{C}+$ Scheduling $\% 2 \mathrm{C}+$ and+Controlling $\% 2 \mathrm{C}+12$ th+Edition-p9781119165354

Leroy, S. (2009). Why Is It So Hard To Do My Work? The Challenge of Attention Residue When Switching Between Work Tasks. Organizational Behavior and Human Decision Processes, 109(2), 168-181.

Mack, N. (2005). Qualitative Research Methods: A Data Collector's Field Guide.

Margolis, J. (2020). Multiple Team Membership: An Integrative Review. Small Group Research, 51(1), 48-86. doi.org/10.1177/ 1046496419883702 
Mortensen, M., Gardner, H. K. (2017). The Overcommitted Organization. Harvard Business Review. https://hbr.org/2017/09/theovercommitted-organization

Mortensen, M., Hadley, C. N. (2020). How to Prepare Your Virtual Teams for the Long Haul. Harvard Business Review. hbr.org/ 2020/05/how-to-prepare-your-virtual-teamsfor-the-long-haul

Mortensen, M., Woolley, A. W., \& O'Leary, M. (2007). Conditions Enabling Effective Multiple Team Membership. IFIP International Federation for Information Processing. doi.org/10.1007/978-0-387-73025 -7_16

O'Leary, M., Mortensen, M., \& Woolley, A. (2011). Multiple Team Membership: A Theoretical Model of Its Effects on Productivity and Learning for Individuals and Teams. Academy of Management Review. https://doi.org/10.5465/AMR.2011.61031807

Ozorhon, B., \& Oral, K. (2017). Drivers of Innovation in Construction Projects. Journal of Construction Engineering and Management, 143(4), 4016118. doi.org/10.1061/ (asce)co.1943-7862.0001234

Palumian, Y., Gunawan, K.A., Tarigan, Z.J.H., and Umbara, A.N. (2021). The Role of Knowledge Sharing and Learning Orientation in Improving Innovative Work Behavior among Millennials in Indonesia. International Journal of Business Studies, 4(1), 74-84, doi: https://doi.org/10.9744/ijbs.4.1.74-84

Pluut, H., \& Flestea, A. M. (2014). Supplemental Material for Multiple Team Membership: A Demand or Resource for Employees? Group Dynamics: Theory, Research, and Practice, 18(4), 333-348. doi.org/10.1037/gdn0000016. supp

Pratiwi, S. (2019). Pengaruh Gaya Kepemimpinan Terhadap Kinerja Tim Pada Proyek Konstruksi. Universitas Pendidikan Indonesia. repository.upi.edu/42326/

Rapp, T. L., \& Mathieu, J. E. (2019). Team and Individual Influences on Members' Identification and Performance Per Membership in Multiple Team Membership Arrangements. Journal of Applied Psychology, 104(3), 303. doi.org/10.1037/ap10000344

Setyawan, A., Dharmayanti, D., and Foedjiawati. (2020). The Impact of Team Building Intervention on Internal Communication in Lia S Associates Branding \& Design Organizations. International Journal of Business Studies, 3(2), 85-93, doi: doi.org/10.9744/ijbs.3.2.8593
Siswanto, A. B., \& Salim, M. A. (2019). Manajemen Proyek. CV. Pilar Nusantara.

Smith, T., Kirkman, B., Chen, G., Lemoine, G. J. (2018). Research: When Employees Work on Multiple Teams, Good Bosses Can Have Ripple Effects. Harvard Business Review. https://hbr.org/2018/09/research-whenemployees-work-on-multiple-teams-goodbosses-can-have-ripple-effects

Soyemi, O. (2018). A Multi-Level Study of Perceived Multiple Team Membership Variety and Its Effects on The Outcomes of Productivity And Innovation. Aston University. www.semanticscholar.org/paper/A-multilevel-study-of-perceived-multiple-team-andSoyemi/093f1ae608b9ee8b619f871

71f0a5ba2864a4d72

van de Brake, H. J., Walter, F., Rink, F. A., Essens, P. J. M. D., \& van der Vegt, G. S. (2018). The Dynamic Relationship Between Multiple Team Membership and Individual Job Performance in Knowledge-Intensive Work. Journal of Organizational Behavior, 39(9), 1219-1231. doi.org/10.1002/job.2260 van de Brake, H. J., Walter, F., Rink, F. A., Essens, P. J. M. D., \& van der Vegt, G. S. (2019). Benefits and Disadvantages of Individuals' Multiple Team Membership: The Moderating Role of Organizational Tenure. Journal of Management Studies. doi.org/ 10.1111/joms.12539

Walsh, K. (2003). Qualitative Research: Advancing The Science and Practice of Hospitality. Cornell Hotel and Restaurant Administration Quarterly, 44(2), 66-74.

Xue, X., Zhang, R., Wang, L., Fan, H., Yang, R. J., \& Dai, J. (2018). Collaborative Innovation in Construction Project: A Social Network Perspective. KSCE Journal of Civil Engineering, 22(2), 417-427. doi.org/10.1007 /s12205-017-1342-y

Zika-Viktorsson, A., Sundström, P., \& Engwall, M. (2006). Project Overload: An Exploratory Study of Work and Management in MultiProject Settings. International Journal of Project Management, 24(5), 385-394.

\section{Appendix 1}

\section{What's in this survey?}

This interview survey will contain questions related to multiple team membership (MTM) or can be called multiple team membership. MTM is used to describe a situation where an individual is simultaneously a member of two or more teams at any given time. 
This survey is not a test and there are no right or wrong answers. The purpose of these questions is to ensure personal opinion about the questions asked in the survey. There are 3 parts to this question session. The first part deals with questions related to job descriptions, the second part deals with multiple team membership, and the last part deals with performance and teams after the implementation of MTM.

\section{How long will this interview take?}

This interview will take about 20-30 minutes.

\section{How do I answer this survey?}

The researcher will read all the questions and the task of the resource person is to answer all the questions honestly and the researcher will record and record this activity.

\section{Who will see my answer?}

The information you provide is completely confidential. No one, apart from researchers Jennyamor Ramadhani, ST and Dr. Ahyar Yuniawan M.Si who is supervising this project will see your answers. Your answers will provide research data for scientific articles that will later be published in academic journals. However, individuals, teams and organizations will remain anonymous.

\section{Interview Questions}

\section{General Information:}

1. Name

2. Age

3. Gender

4. Education (Highest)

5. Experience

6. Company

7. Department

8. Job Description

\section{Application of Multiple Team Membership}

1. Have you been or are you participating in more than one project at the same time?

2. Is the project you are working on from the same company where you work or can it be from another company?

3. What projects are they?

4. In one time, how many projects have you received/worked on?

5. Who assigned you to the project? (internal supervisors such as the same department or requests from external sources such as freelance projects or friend requests)

6. How long is the duration of the work or the target of each team? (mention how many months and when the project target must be completed)

7. In one day how many hours do you work? (in hours)

8. In each project team, how much time do you dedicate? (in hours or percent)

9. Have you ever worked more than the working hours determined by the company or those determined by law due to multiple team membership? (if so why, and if not what is the reason)

10. Is working excessive hours considered overtime? (if so is overtime paid by the company?)

11. Have you ever experienced fatigue, stress, workload while participating in this MTM?

12. Have you ever had disagreements with your team members on each project?

13. If so, did it affect the running of your projects?

14. In your opinion, what are the advantages of implementing the multiple team membership work system?

15. In your opinion, what are the disadvantages of implementing a multiple team membership work system?

16. Do you prefer to work in multiple team membership or only on one team at a time (fluid team)?

17. If you were given another chance to work in multiple team membership, would you be willing? Why is that? Give the reason!

18. How do you think you can stay focused and be able to work on multiple projects at the same time?

\section{Individual Project Performance}

1. Is your type of jobdesc/role the same among the many projects you work on?

2. Do your projects use the same knowledge, processes or technology?

3. Do the projects you hold have remote locations?

4. What is the status of the projects that you do simultaneously at one time? Did everything work out? did it finish on time? what about the budget? is it on target? 
5. What is the quality of the progress and results of these projects? Does it satisfy the leaders?

6. Are you satisfied with your performance even though you have to lead many projects at once?

\section{Team Project Performance}

1. Do your projects have different team members?

2. Is your team able to meet the objectives of the projects?

3. Does your team carry out the project work process according to the SOP (Standard Operating Procedure)?
4. Does your team always respond quickly when problems arise?

5. Is your team always successful in solving these problems?

6. Do team members always implement new ideas, methods or procedures to improve the quality of project work?

7. Do you feel your team is a productive and innovative team?

8. Are you satisfied with your team's performance?

\section{Corresponding author}

Jennyamor Ramadhani can be contacted at: amorajenny97@gmail.com 